الدورية العلمية لكلية الفنون الجميلة ـ جامعة الإسكندرية

SJFA

Scientific Journal of the Faculty of Fine Arts Alexandria University

Print ISSN: 2356-8038

Online ISSN: 2535-227x

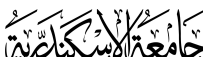

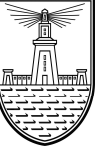

\title{
The Social Impact and Seafront Development
}

\author{
K. H. El Tawil ${ }^{1}$, S. M. Al Arnouty ${ }^{2}$, H. Abo Al Fadle'
}

\begin{abstract}
This paper discusses a major problem which is the loss of connection between the urban designer and the stakeholders leading to loss of balance during the design process between the four sides of the stakeholders (Government, Investors, Community, and users) and developing new inefficient projects of high cost with and less productivity, which fail gradually during the project operation stage.

Aiming to reach a well-designed seafront on all stages helping on improving the stakeholder's lifestyle.

The researcher main methodology depends first on the defining of the seafronts, the second part is studying the different factors of social impact and their positive and negative impact, the third stage analyzing the previous developments that occurred to Alexandria seafront applied to the case study and in the final stage the researcher the recommendations are put for developing the seafront studied.

It is proposed that by applying the final recommendations most of the seafront problems will be solved.
\end{abstract}

KEYWORDS: Seafront, Urban up grading, Urban development, Social impact, Urban identity, Connectivity.

\section{INTRODUCTION}

Seafronts were the main place of settlements of commercial buildings and community development along ages.

The researcher main aim is to know wither the performed developments have a positive or a negative social impact, through the two stages of seafront development of Alexandria depending on eleven factors (demographic changes, accommodation and housing, health impact, cultural impact, facility requirement, economic issues, cumulative impact, transportation issues, social

\footnotetext{
${ }^{1}$ Master's in architecture at AAST, Senior Architect at Prof. Hatem El Tawil Office.

karimeltawil@ymail.com

${ }^{2}$ Vice dean for post graduate studies and scientific research, Professor, Faculty of Fine Arts, Alexandria university drsahar_elarnaouty@yahoo.com.

${ }^{3}$ Associate professor, Faculty of Fine Arts, Alexandria universiy.
} 
cohesion and harmony, community and special identity, and political aspects), defining the seafront and its development, putting some guiding lines for the existing seafronts, setting some design criteria and guiding lines for the urban design while designing new cities and developing seafront design factors to reach a good urban life quality.

And the researcher objectives are going behind the main reasons behind the development of waterfronts and seafronts through the time and this may lead to the deterioration of urban spaces. And discussing the duel impact between people and seafronts through the interaction, going through the different factors of social impact improvement and how can it be applied and what is its impact on the people and the urban space, and the different types of connection and their applications along ages and how did it develop, discussing some solutions for the current riverfronts, and some futuristic visions with unusual ideas for the riverfronts which can achieve a better seafronts.

The research progress will depend on Analyzing the seafronts in order to come up by the main factors affecting the seafronts, studying the different methods and types of factors and their impact on different project stages (Site analysis, Design process, Construction process, Operation process, Maintenance process, Deconstruction process).

The research works on developing the seafronts to Improving the quality of life, the transportation street networks, and help on integrating the different sections of the society.

The research works as well on the creating new green open spaces integrated within the city's fabric and solving the problem of unemployment by providing thousands of new jobs for Egyptian labor either at the construction stage or the performance stage and revitalization of the city fabric by creating a new spine.

\section{SEAFRONT DEVELOPMENT}

The seafront is a visual, physical and psychological relationship between the land and the water body in addition to the relation between the elements of the surrounding the water body (natural elements and human made elements), the human made elements should be in coherence with each other and with the surrounding natural environment.

The human made elements main and dominant element is the building with its different types, forms, and functions the buildings should be visually and functionally coherent (as shown at figure 1.)
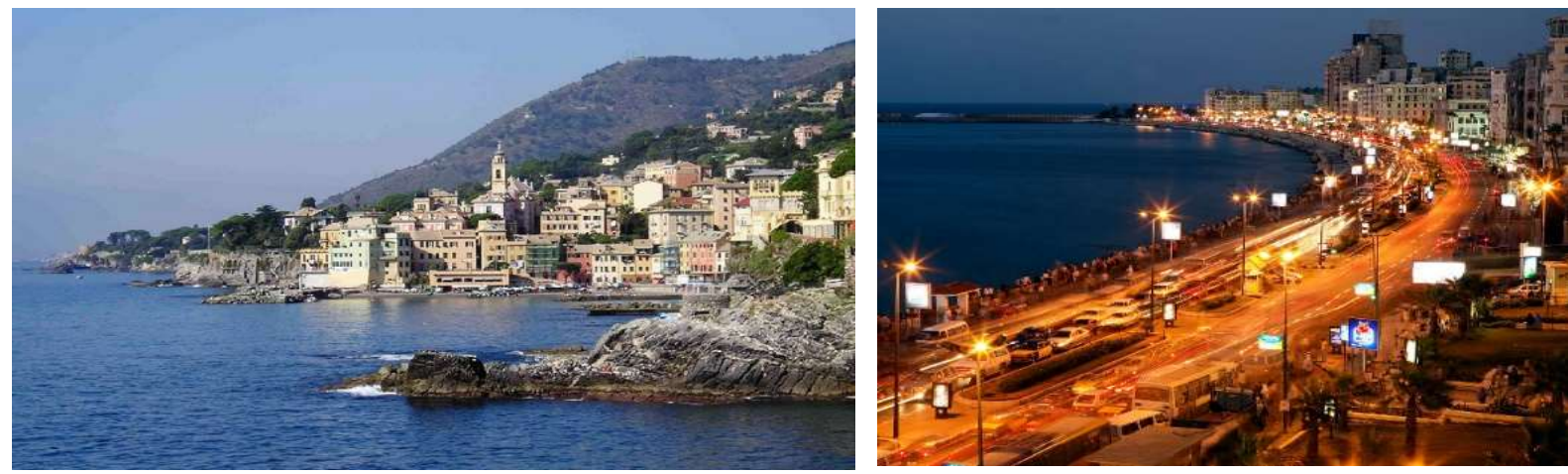

Figure 1 Seafront of Bogliasco, small town in Liguria, Italy (shutterstock.com, 2015), Seafront of Alexandria, Egypt (anatoliansky.co.uk, 2015) 


\section{SJFA}

Scientific Journal of the Faculty of Fine Arts Alexandria University

\section{SOCIAL IMPACTS}

Social impact refers to the consequences of any urban spaces development that alter the ways in which people live, work, play, relate to one another, organize to meet their needs and generally cope as members of society. In some interpretation, social impact may also include the change in norms, values, and beliefs that guide interpersonal relationship and people's relationship with the society, as well as an interconnected net effect of urban space developments on a community and the well-being of individuals, families and organizations. (IOCGPSIA, 2003)

\subsection{Demographic Changes}

The demographic changes are concerned by the community needs and expectations, the population changes, demographic composition and influx and out flux as well as cultural and socioeconomic profiles helping the designer within the first basic steps of the design process to know the preferable functions and scale needed to serve the stakeholders.

\subsection{Accommodation and Housing}

Accommodation and housing are concerned with affordable housing, housing diversity, and housing adaptability and housing relocation and dislocation, analysis shows the capability of the stakeholders to rent or buy units (residential, commercial and administrative) and the users' capability to different types of units.

\subsection{Health Impact}

Health Impact are concerned with Youth, Health effects of water and air quality, Toxic wastes \& hazardous chemicals, Environmental health (noise, smell, visual impacts), Food security - access to healthy, affordable food environments encourage participation in healthy lifestyle studying the project site making a SWOT analysis to define the present impacts and how to treat them as well as the futuristic intentions that may be caused by location threats and opportunities, Mortality rate and Median age are both factors that help the designer know with whom he deals and their capabilities.

\subsection{Cultural Issues}

Cultural Issues are concerned with needs of people not speaking native languages, Aboriginal \& Torres Strait islander issues and both of these kinds of users should be put in consideration to know their needs and the best method to make them capable of reading the space, Religious needs and practices, Continuity of local culture, Cultural life, Continuity or effects on local history and these as well help the designer in taking the decision within the step of zoning and conceptual design

\subsection{Facility Requirements}

Facility Requirements are concerned with Needs for community services \& facilities, Recreation needs, Government provided facilities, Connectivity and access to local shops, schools, community \& health service and facilities and how these elements effect the user.

\subsection{Economic Issues}


Economic Issues are concerned with business development impact on the urban growth, local employment generation rate and the personal income and whether it is enough or not, unemployment rate and how to reduce it.

\subsection{Cumulative Impact}

Cumulative Impact are concerned with Redundant facilities \& possible reuse, Effect of similar types of developments in the locality how they can it help in calculating the chain impact.

\subsection{Transport Issues}

Transport Issues are concerned with access equitable for all, Will public transport be required to provide access, what are the existing arrangements, Location of routs and stops provision of appropriate infrastructure, Opportunity to utilize alternative means of transportation (including walking \& cycling).

\subsection{Social Cohesion and Harmony}

Social Cohesion and Harmony are concerned with Opportunity to have /build social networks, Participation in community life, Environments that foster social cohesion \& community connections inclusiveness versus alienation, creation of exclusivity or inequality, Tolerance of diversity through different recreational and social activities.

\subsection{Community and Special Identity}

Community and Special Identity are concerned with Aesthetic and visual impact, Amenity, Sense of place, Objectives for specific neighborhoods (including place-based plans), Spaces to accommodate community event, cultural programs, Public areas with diversity of spaces for social activities/groups reflection and quite places, Neighborhood safety, Community identity, Community severance, Community cohesion.

\subsection{Political Aspects}

Political Aspects are ' concerned with Distribution of power and authority, Identification of stakeholders, Identification of interested and affected parties, Identification of leadership capability and characteristics.

\section{SEAFRONT DEVELOPMENT IN ALEXANDRIA}

The seafront in Alexandria used to have a great opportunity within the development of the city where most of the governmental associations focused on due to its location and users (tourists, students, and other people), the seafront in Alexandria is set to be one of the major touristic targets, as well as one of the major motorists linking roads linking between the whole city due to the linearity of Alexandria as a city.

\subsection{Seafront development stages}

Seafront development majorly focused on the serving of the motorists neglecting the people needs, the first stage of development started at year 2000 by widening the street and increasing the number of lanes through backfilling part of the sea, the second development stage started at year 2018 , focusing mainly on the economical wise through the relocation of some recreational places and the positioning Sidi-Gaber bridge which is elevated over the main street. 


\section{SJFA}

Scientific Journal of the Faculty of Fine Arts Alexandria University

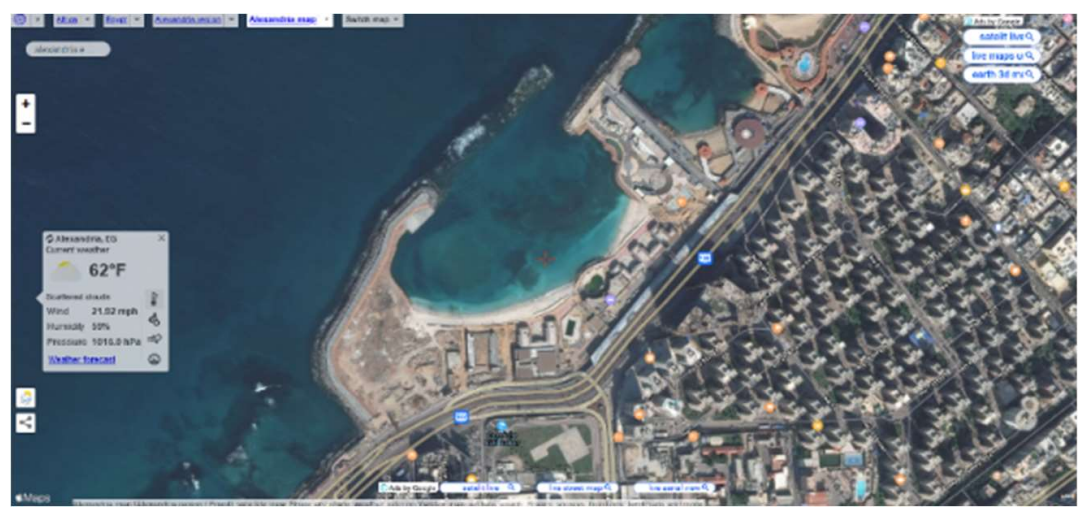

Figure 2 last stage within the development (satellites.pro, 2020)

\subsection{Seafront development impacts}

\section{- Demographic Changes}

The first stage of the development caused the increase in influx of population whether the permanent or the temporary, while the second stage was not effective within this point.

The community needs that were achieved by the first stage were more than the second stage even that the second stage had a negative impact on the first one.
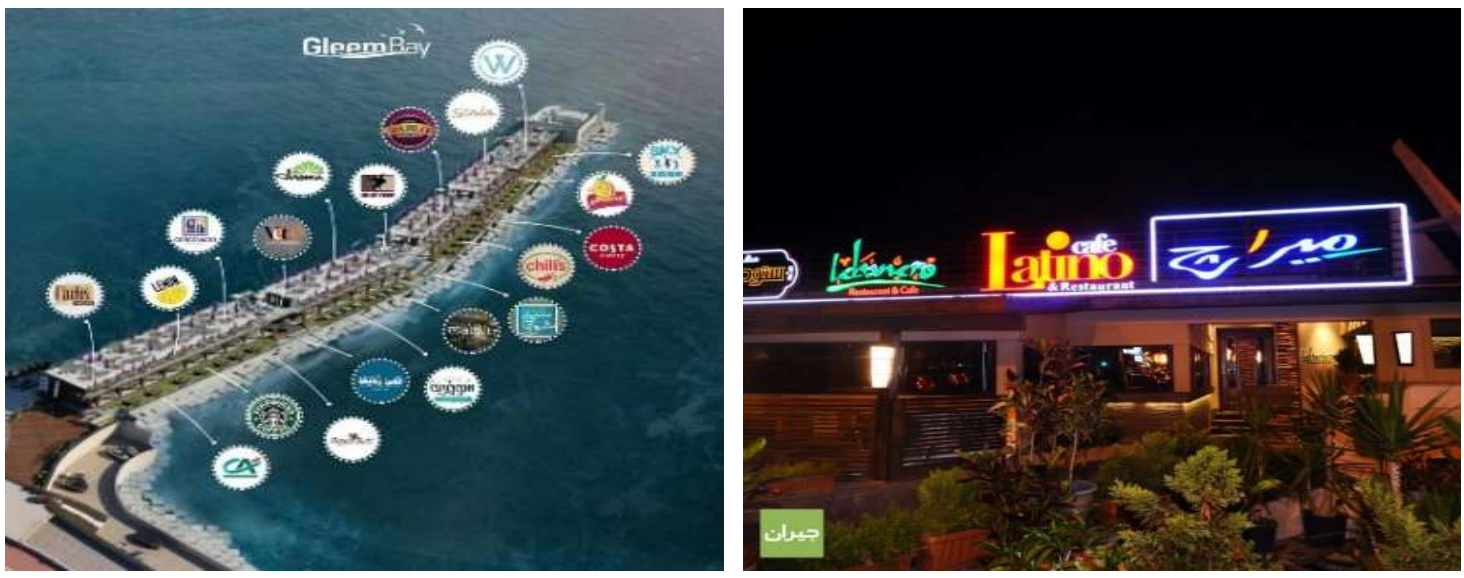

Figure 3 Gleem bay (Alexandria_egy1, 2020), Mirage (jeeran.com, 2020)

- Accommodation and Housing 
With the first stage of development accommodation and housing types differed in heights as an example san-Stefano tower which exceeded the thirty floors creating high dense points all over the path of the seafront as well as the types of residential and commercial units that started aiming a higher category of users, the second stage did not have a great impact on the accommodation and housing except for the zone of Sidi-Gaber which was chosen to be a location
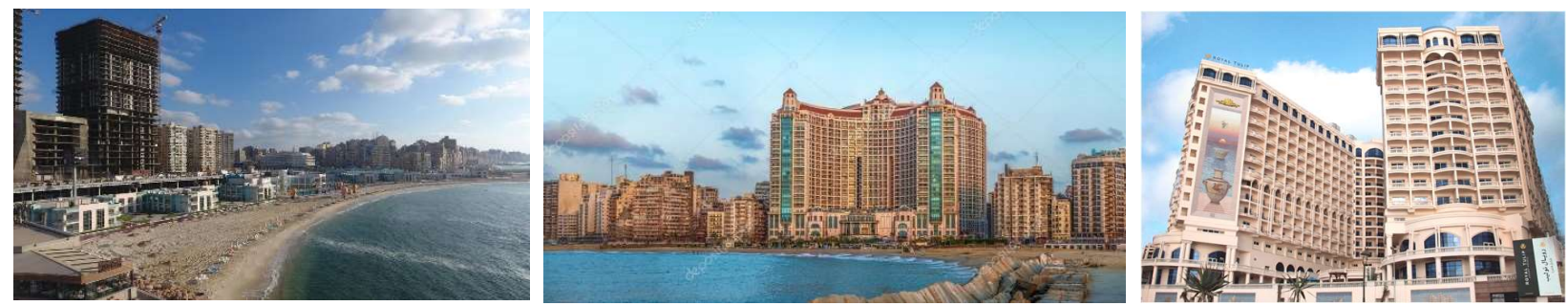

Figure 4 Golden jewel hotel (booking.com, 2020), Four season hotel (depositphotos.com, 2020), Tolip hotel (tolipalexandria.com, 2020)

to a new hotel that blocked the view of the residential buildings behind.

- Health Impact

- The first development stage cased the increase of the air pollution due to the increasing of the traffic density while the second stage cased the increase in water pollution due to the presence of new place which was built directly on the sea without leaving any buffer zones as well as the increase in the depression feeling and other psychological due to the loosing of the sea view (The only natural view within Alexandria left for public) which the Alexandrians used to react with.

\section{- Cultural Issues}

The cultural issues and the way of thinking within both stages of the development was not given the priority

\section{- Facility Requirements}

Both developments did not put the facility requirements in consideration depending on the surrounding uses facilities.

\section{- Economic Issues}

The first stage of development improved the economic opportunities given to the investors through creating a great view and a link binding Alexandria longitudinally, the second stage improved the economic opportunities but did not put the different people categories in consideration giving the priority to the high-income users.

\section{- Cumulative Impact}

The criminal and aggressive reactions will increase by the time due to the unbalanced development especially through the economic, cultural, community and special identity and political factors.

\section{- Transport Issues}




\section{SJFA}

Scientific Journal of the Faculty of Fine Arts Alexandria University

Transportation development was not effective enough even that it was strongly effective at the beginning since the main aim from widening the street was improving the motorists flow and this case did not continue due to the increase of motorists density, while the second stage started weakly but due to the dis respecting of the designer to the users needs and economic capabilities,
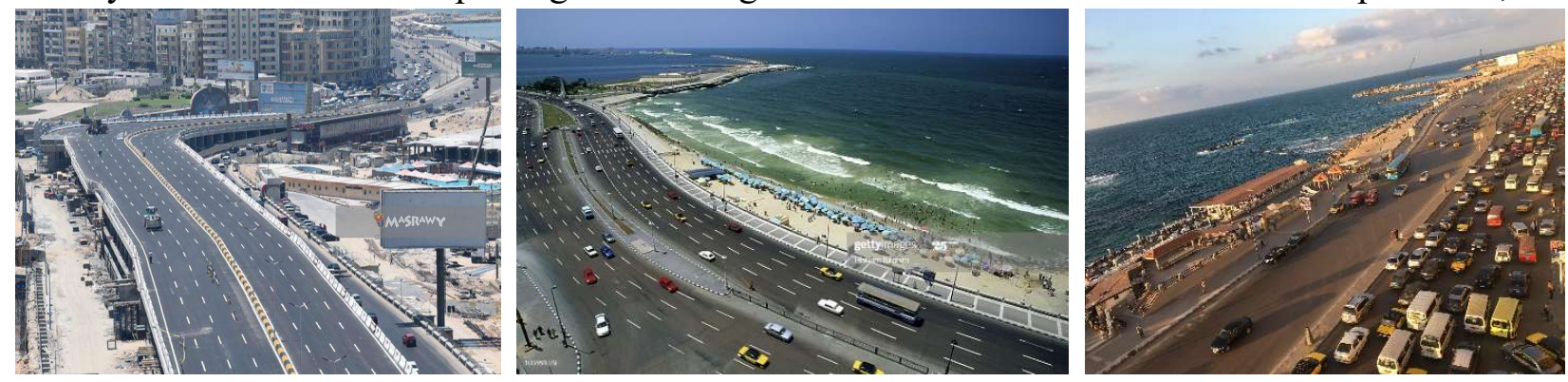

Figure 5 Sidi-Gaber bridge (masrawy.com, 2020), the cornice street development start and its capacity after five years (gettyimages.co.uk, 2020; wikimedia.org, 2020)

although it lasted till now

\section{- Social Cohesion and Harmony}

Social Cohesion and Harmony was improved by the first development through increasing the walkability and linking the city together longitudinally as well as offering a place which is preferable for cycling generating an active zone while the second stage depended on the restaurants, cafeterias and siting zones where not all economic and cultural categories were put in consideration.

\section{- Community and Special Identity}

Both developments cased the loss of special identity and sense of place, also factors of safety were not given apriority, as well as the diversity in the design where most of the places are designed for certain categories. identity.

The changing of type of palm trees in the first stage made Alexandria loose part of its

\section{- Political Aspects}

In both stages of the development stakeholders and interested and affected parties were not well identified especially within the second stage of development were the balance moved toward the investors neglecting the users and how can their needs be implemented within the design.

\subsection{Demographic Changes}

\section{RECOMMENDATIONS}

- Calculating the population disturbance that will happen due to the development, through different sages of the project (the number of workers influx and outflux during the construction process, the number of new users of the residential and commercial developed, etc.).

- The needs of people and their expectations according to the location upon the different time intervals of the project life time.

\subsection{Accommodation and Housing}


- Reducing the node effect especially within high dense zones, and spreading the different uses horizontally.

- Improving the design diversity to cooperate with different economic and cultural categories.

\subsection{Health Impact}

- Reducing the traffic density that occurs the air pollution.

- Redirecting the drainage lines away from the sea water.

- Restricting building any kind of buildings or fences within the sea shore.

\subsection{Cultural Issues}

- Analysing the people way of thinking

- Studying the project location historical back ground, and its actions affected the uses

\subsection{Facility Requirements}

- Analysing the people needs of facilities and their locations.

\subsection{Economic Issues}

- Balancing between different income and cultural categories of users within development.

- Balancing between economic wise and functions that serve different age categories.

\subsection{Cumulative Impact}

- Analysing the stockholders' way of thinking and kind of reactions taken, its timing and the needed magnitude.

\subsection{Transport Issues}

- Improving the public transportation capacity

- Improving the public transportation lines

- Improving the public transportation diversity

\subsection{Social Cohesion and Harmony}

- Returning the visual and physical longitudinal link along the sea promenade

- Linking between the waterfront activities and the social and community activities.

- Developing a secure lane for cycling.

\subsection{Community and Special Identity}

- Putting the special identity and sense of place as priority during design phase.

- Widening the targeted sector of the society leading to more diversity.

- Improving open spaces safety factors.

\subsection{Political Aspects}

- Distributing the missions of the construction and operational stages upon different specialists and responsible authorities under one regulatory authority. 
- Balancing between the different parties of the project (community, investors, and users).

\section{REFERENCES}

Alexandria_egy1.(2020, 3 18). Retrieved from Alexandria egy1: $\mathrm{https}$ ://witter.com/Alexandria_egy1/status/1236839531124490242

anatoliansky.co.uk. (2015, 3 5). Retrieved from anatoliansky.co.uk: http://www.anatoliansky.co.uk/egypt-holidays/alexandria/ Bahraini, S. (2018). Urban Design Process. (S. Edition, Ed.) Tehran University Press, 139. booking.com. (2020, 3 18). Retrieved from booking.com: https://www.booking.com/hotel/eg/golden-jewel.html

Cass, N., Shove, E., \& Urry, J. (2005, July 29 ). Social exclusion, mobility and access. The Sociological Review, 53(3), pp. 539-555.

depositphotos.com. (2020, 3 18). Retrieved from depositphotos.com: https://depositphotos.com/59449913/stock-photo-alexandria-san-stefano-skyline.html Furlong, \& Andy. (2013). Youth Studies: An Introduction. USA: Routledge. gettyimages.co.uk. (2020, 3 18). Retrieved from gettyimages.co.uk: https://www.gettyimages.co.uk/detail/photo/el-corniche-and-city-beach-alexandria-egyptroyalty-free-image/100464079

IOCGPSIA. (2003). Principles and Guidelines for Social Impact. KOLKATA. Retrieved from upenn.edu.

jeeran.com. (2020, 3 18). Retrieved from jeeran.com: https://m.jeeran.com/alexandria/miragegelem-complex-foods-alexandria

Kaufmann, V. (2002). Re-Thinking Mobility: Contemporary Sociology (Transport and Society). London, New york: Routledge.

masrawy.com. (2020, 3 18). Retrieved from masrawy.com: https://www.masrawy.com/news/news_regions/details/

Massot, M., \& Orfeuil, J. (2005). La mobilité au quotidien, entre choix individuel et production sociale. Cahiers internationaux de sociologie, 81-100.

Mukherjee, P. (1992, 6 18). planningcommission.gov. Retrieved 1 9, 2019, from planningcommission.gov: http://planningcommission.gov.in/plans/planrel/fiveyr/8th/vol1/8v1pre.htm satellites.pro. (2020, 3 19). Retrieved from satellites.pro: https://satellites.pro/Alexandria_map.Egypt\#31.229683,29.940663,17

shutterstock.com. (2015, 8 6). Retrieved from shutterstock.com: http://www.shutterstock.com/pic-92873959/stock-photo-seafront-of-bogliasco-smalltown-in-liguria-italy.html

tolipalexandria.com. (2020, 3 18). Retrieved from tolipalexandria.com: https://www.tolipalexandria.com/en-us

wikimedia.org. (2020, 3 18). Retrieved from wikimedia.org:

https://commons.wikimedia.org/wiki/File:Alexandria_Corniche_,photo_by_Hatem_Mou shir_7.jpg 


\section{الاورية العلمية لكلية الفنون الجميلة - جامعة الإسكندرية}

SJFA

Scientific Journal of the Faculty of Fine Arts Alexandria University

\section{التأثير الاجتماعي وتطوير السواحل}

كريم الطويل1 ، سحر الأرناؤوطي22 ، هبة أبو الفضل. 3

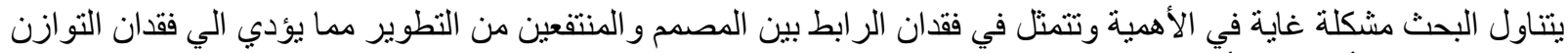

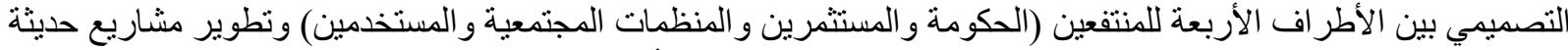

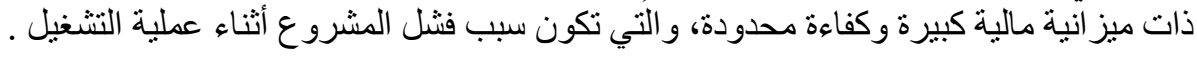

يهدف البحث للوصول الي تصميمات لواجهات بحرية تساعد على تحسين النمط المعيشي للفئات المنتفعة من التطوير .

البحث ينقسم الي أربع مر احل، المرحلة الأولي هي تحديد الو اجهات البحرية والمرحلة الثانية هي دراسة العو امل المختلفة المؤثرة

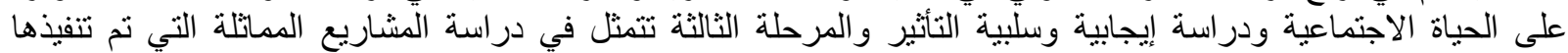

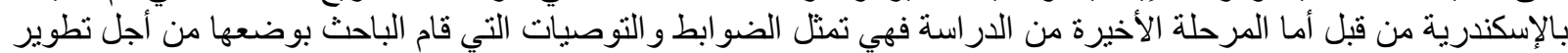

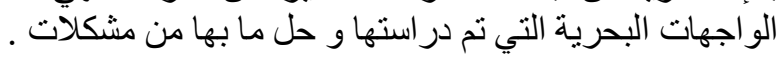

يفترض باستخدام ما سبق من توصيات أن يكون تطوير الو اجهات البحرية أكثر كفاءة من الناحية الاجتماعية والمادية الكلمات الرئيسية: الواجهة البحرية ، التطوير الحضري ، التنمية الحضرية ، الأثر الاجتماعي، الهوية الحضرية ، الاتصال. sifa@alexu.edu.eg 